\title{
A NOVEL TECHNIQUE TO INCREASE THE LOAD CAPACITY OF THE STEEL PIPE PILE
}

\author{
NiHAD B. SALIH \\ Dept. of Irrigation Engineering, College of Engineering, University of Sulaimani, Kurdistan Region-Iraq
}

(Received: July 25. 2017; Accepted for publication: November 27, 2017)

\begin{abstract}
In this study a new technology was generated for steel pipe piles to increase their bearing capacity. The technology consists of addition of horizontal screws similar in terms of size and type to the circumferential surfaces of the pile. The additional parts were equal in length and thickness in order to focus on the technology process and response rather than understanding the role of the screws dimensions. The modified pile was constructed in a laboratory physical box model. Pile load test was conducted on both of modified and ordinary steel pipe piles. The pile load test was performed by notable loads and fixed time duration, which might help in terms of transmitted forces from heavy structures. The results of this study showed that the model gained a considerable resistance, which noticed with the settlement magnitude decrease of the modified pile. Significantly, the recorded settlement was reduced because of the addition of horizontal screws. 9.8, 31.3, $33.3 \& 35.9 \%$ settlement reductions were obtained for 8.8, 35, 156 \& $191 \mathrm{kPa}$ applied stress respectively.
\end{abstract}

KEYWORDS: Steel pile, Cyclic-loading, Fine-grained soil, Time-settlement.

\section{INTRODUCTION}

One of the original instances of the art and science of a civil engineer is driving of bearing piles to support structures. Piles are columnar elements in a foundation. Pile foundation is a deep foundation type uses for weak soils and to support large structures and tall building, which facing various types of applied and natural forces.. The job of piles is transferring of loads from the superstructure to a suitable subsurface soil layers. Load transferring is through weak compressible stratum or via water, onto stiffer or more dense and less compressible soils or onto rock (Tomlinson and Woodward, 2014). In recent years, the use of piles practically has sharply increased (Ghazavi and Ahmadi, 2008).

A pile is a slender, structural member installed in the land to transfer the structural loads to soils at some considerable depth underneath the foundation of the structure. Axial loads, lateral loads and moments are the structural loads. In natural fine and coarse-grained soils where the ground water table is at a large depth, it is also common to use pile foundations. In semi-arid and arid regions pile foundations are used to resist large loads and limit the settlements. Characteristically, pile foundations are considered to be selected for many natural soil cases such as saturated, dry or submerged situations (Douthitt et al., 1998; Costa et al., 2003; Georgiadis et al., 2003; Vanapalli and Taylan, 2011).

Steel and concrete are the main types of materials used for piles. Piles are driven, drilled or jacked into the ground and connected to pile caps. Depending on the type of soil, pile material and load transmitting characteristic, piles are classified accordingly. Reinforced concrete pile in the late $19^{\text {th }}$-century and early $20^{\text {th }}$-century was developed as a structural medium (Tomlinson and Woodward, 2014). For common construction work, reinforced concrete mostly replaced timber for high-capacity piling. Steel, because of its ease of manufacturing, handling and its capability to withstand hard driving has been used, to an increasing extent, for piling. So, problems of corrosion in marine structures have been overcome by the introduction of durable coatings and cathodic protection (Tomlinson and Woodward, 2014). After year 1989, when examining the use of steel pipe piles in many projects is successful, use of steel pipe piles in bridge foundation has increased (FinnRA, 2000).

Screw piles are common in use for more than 160 years. initially, throughout using eight 20 feet long torque bars, screwed piles were installed at 
10 feet per hour. Use of screw piles was largely for supporting structures and bridges constructed over weak or wet soils. Screw piles are ideal to resist tension and axial compression forces (Clayton, 2005). These piles can offer important advantages such as speediness and simplicity of installation and by presenting a decrease in the offsite disposal of drilling spoil. Screw piles are usually manufactured from steel, and sometimes galvanized in order to protect against corrosion (Tappenden, 2007; Practice Note 28, 2015).

Settlement, which controls the design in most cases of pile design, should be studied simultaneously with the bearing capacity. Although by the time a pile has failed in terms of bearing capacity, pile foundations are often designed based on the calculations of allowable bearing capacity (Seo et al., 2008). Evidence of an increase in pile capability with time is a well established, primarily when piles are driven into fine-grained soils (Axtell et al., 2004).

In order to understand the real capability of piles in the field, pile load testing can be carried out. Static and dynamic loading systems are common to conduct the pile load test. The results from the static load tests are reported by Adsero (2008), Herbst (2008), and Lemme (2010).

Case studies for pile testing help to increase the matter knowledge. The case studies also help a judgment when taking into account projects in practice. Several research studies have considered case studies concerning pile loading tests (Dasenbrock, 2007; Olson, 2003; Ackley \& Sanders, 1979; Kessler, 1979).

Previously, laboratory models were carried out significantly in many studies. Dash et al. (2003) performed model tests in the laboratory to study the response of reinforcing granular fill overlying soft clay beds. Load tests were conducted on the laboratory model strip footings resting on granular trench and wrapped granular trench by Unnikrishnan et al. (2011). El-Sawwaf and Nazir (2012) presented an experimental study of the behavior of an eccentrically loaded model ring footing resting on a compacted replaced layer of sand that overlies an extended layer of loose sand. Ornek et al. (2012) presented the use of artificial neural networks, and the multi-linear regression model to predict the bearing capacity of circular shallow footings supported by layers of compacted granular fill over natural clay soil. Laboratory experiments have been carried out by Fattah et al. (2014) to study the grouting of some gypseous soils by acrylate liquid. Investigational study was directed by Al-Waily et al. (2013) to establish the correlation between piled raft foundation and two soil improvement techniques, stone columns and lime columns to evaluate the bearing improvement ratio for the soft clay soil with three values of undrained shear strength, 8 , $10 \& 12 \mathrm{kPa}$. After that, the study of Al-Waily et al. (2014) aimed to investigate the behavior of circular footing on cohesive soil stabilized by gravel using laboratory model tests. Test results indicated that the footing performance could be appreciably improved by the addition the gravel to the cohesive soil. The model tests were carried out in a test tank of size, $(240 * 240 * 265) \mathrm{mm}$. Granite stone chips were used for the formation of stone columns. Model tests were carried out by Fattah et al. (2013) in a test box model manufactured of steel $(1100 * 61000 * 6800) \mathrm{mm}$, made of steel plates (6 $\mathrm{mm}$ in thickness). The container was sufficiently rigid and exhibited no lateral deformation during the preparation of the bed of soil and during the tests and the used mechanism was similar to the conventional piles or piers. Model tests were carried out by Fattah and Al-Waily (2015) in a test tank manufactured of steel with dimensions of $500 \mathrm{~mm} \times 500 \mathrm{~mm} \times$ $500 \mathrm{~mm}$, made of steel plates $6 \mathrm{~mm}$ in thickness. The models used for the reclaimed asphalt pavement as a replacement material underneath a footing resting on soft clay. Gueguin et al. (2015) addressed the geotechnical engineering problem of evaluating the ultimate bearing capacity of a strip foundation resting upon a reinforced soil, by means of the yield design homogenization approach.

In this study, the general improvement in capacity of the pipe piles is focused. The measured increase in capacity is achieved with time as determined from axial static compressive load tests. It sheds the lights on the prediction of the additional capacity due to modification of a steel pipe pile with added parts (screw). The suitability of the proposed modification method is highlighted through a comparison with an ordinary steel pipe pile. Laboratory tests and the piles' settlement record are performed and then the required data analysis is conducted. The required time of preparation and testing are under control and the real loading time is the important part to be considered. 


\section{OBJECTIVES}

The specific objectives of this study are as follows:

i. To investigate the suitability of addition of circumferential screws to increase pile capacity.

ii. Cumulative stress application on normal and modified steel pipe piles.

iii. Monitoring normal and modified steel pipe piles settlement to support fine-grained soil.

\section{MATERIALS AND METHODS}

A new laboratory method with steel pipe pile has been developed. It allowed to conduct a more realistic simulation of steel pipe pile in finegrained soil. The height of the soil column included five layers of compacted soil sample, which was increased up to the height of the physical model and free $5.0 \mathrm{~cm}$ at the model top surface. The compacted soil was made from a fine-grained soil. The compacted soil enabled the observation of the pile capability in such compressible soil in addition to the new added parts (screws) to develop the pile ability. The physical model facilitates the observation of the modified pile capability to increase steel pipe pile capacity as shown in Fig. 2.

Conducted classification tests and determination of skin friction from direct shear test for the real soil sample was explored in the laboratory. Steel pipe piles were used to conduct and achieve the required goals of this study. Static loading system was used and the settlement data was recorded for the chosen cases of the study. Data analysis was carried out in order to obtain a robust understanding of the suitability of the proposed method for the field of pile foundation.

\subsection{Materials}

\subsubsection{Selected soil}

The prepared soil used in this study was remolded considering the obtained physical properties of the collected soil from Qerga area (Latitude $=35.518366$ and Longitude $=$ 45.467432), Sulaimani City, Kurdistan Region of Iraq. The area was selected to collect the required disturbed and undisturbed samples for this study. The selected location was rich with thick layers of fine-grained soil. To ensure the comparability in laboratory tests, undisturbed soil samples, reflecting frequently occurring soils $1.0-2.0 \mathrm{~m}$ below the surface, were collected.
Laboratory tests were conducted to find the geotechnical characteristics of the selected soil. A particle-size distribution of the used soil is shown in Fig. 1. The natural engineering properties, consistency properties, compressibility and shear strength properties were conducted based on ASTM Standards (Table 1).

\subsection{Methods}

\subsubsection{Physical model}

The dry soil mass was mixed with $16 \%$ of deionised water by mass and stored for 24 hours to distribute the moisture uniformly. The wet soil was stored in the laboratory under constant room temperature $\left(24 \pm 1{ }^{\circ} \mathrm{C}\right)$ and $90 \%$ of humidity. The moistened soil was then compacted within heavy duty cylindrical steel model (diameter of $50.0 \mathrm{~cm}$ (19.7 inch) and height of $100 \mathrm{~cm}(39.4$ inch)) using a $2.5 \mathrm{~kg}(5.5 \mathrm{Ib})$ hammer to produce a field density of $1.91 \mathrm{gm} / \mathrm{cm}^{3}$. The soil sample was prepared by alternately adding $15 \mathrm{~cm}$ of soil and then compacting using 31-32 hammer blows, to provide the same compaction effort for all layers (BS 1377-4, 1990; Mohammed and Vipulanarofan, 2014).

After filling and compaction, each layer checked in terms of the required density. The model at the bottom included a free distance to the end of the steel pipe pile to leave a free distance for settlement purpose. The friction between the soil sample and the model was minimized using coating by oil painting for the internal side of the model. The container was sufficiently rigid and exhibited no lateral deformation during the preparation of the bed of soil and during the tests.

In this study, two soil models were prepared for each of the two tests required. The first test was for the steel pipe pile without any circumferential holes (Model I)(Fig. 3). While, the second test was carried out for the steel pipe pile with the circumferential holes and added new screws (Model II) as shown in Fig. 4. Samples for both test ran with the same initial soil properties and same experimental procedure and surrounding environment.

\subsubsection{Prepared steel pipe pile}

Stainless steel model pipe piles were used for this study as shown in Figs. $3 \& 4$. The used steel pipe pile model diameter of $20 \mathrm{~cm}$ and height of $30 \mathrm{~cm}$. The pile bottom was closed by a thick steel plate. Two types of steel pipe piles were used. the first one (Model I) was normal without any added parts (screws) as shown in Fig. 3. The second type (Model II) was modified by the addition of screws 
in a certain places on the circumferential surface of the pile as shown in Fig. 4. The added screws was used to increase the pile capacity and obtain more capable steel pipe pile in a simple and a cheap way. In order to determine steel pipe pile capacity for the two mentioned different types, the model piles were statistically-loaded to a certain load and time duration within the test physical model filled with statically-compacted test soil. The added new parts (screws) are shown in Fig. 5.

\subsubsection{Pile loading process}

The pile loading system was conducted as an incremental loading process. The loading started from small stress, which is $0.634 \mathrm{psi}(4.4 \mathrm{kPa})$ on the pile. Then, the applied force increased to stress up to $27.71 \mathrm{psi}(191 \mathrm{kPa})$ on the pile. Each of the $4.4,8.8,17.5,35 \& 70 \mathrm{kPa}$ loading stages was left for 48 hours. While, the $125 \mathrm{kPa}$ loading was left for 4 days, the $156 \mathrm{kPa}$ loading was left for 6 days and finally the $191 \mathrm{kPa}$ loading was left for 10 days. Two dial gauges were used to record the foundation settlement readings. The average reading was considered for both dial gauges, timesettlement and load-settlement relationships were determined.

\subsubsection{Settlement monitoring}

The foundation settlement of both ordinary and modified steel pipe piles were recorded. Two sensitive dial gauges $(0.001 \mathrm{~mm})$ were used for strain observation purposes. Each dial gauge was fixed in a corner in an opposite side as shown in Fig. 2. For each applied load on the pile, each dial gauge reading was recorded started from zero time of load application until no reading was achieved. Time duration for each dial gauge reading was recorded accordingly. After completion of the final stress application (191 $\mathrm{kPa})$, average readings for the two dial gauges were calculated.

\section{RESULTS AND DISCUSSION}

\subsection{Soil properties}

Table 1 shows the field and laboratory properties of the soil considered in this study. The most important properties are as follows: field density of $1.91 \mathrm{gm} / \mathrm{cm}^{3}$, moisture content of $16 \%$, swelling pressure of $25 \mathrm{kN} / \mathrm{m}^{2}$, unconfined compressive strength of $302.6 \mathrm{kN} / \mathrm{m}^{2}$, and based on Unified Soil Classification System (USCS) the soil classified as a high plasticity clay $(\mathrm{CH})$ soil.

\subsection{Physical changes}

The physical changes can be divided into two parts. The first part was the visible changes on the top surface of the tested soil inside the physical model. The second part was external surface of the piles. The noticed changes on the soils top surfaces of both models I \& II can be classified as many skinny and small deep cracks. In addition, some top surface curves were observed after the 30 days of pile loading. The curves were manifested more around the pile location. The curves peaks were higher than the original soil surface after preparation and before pile loading. These changes may be due to the applied static loads for a long duration, which pushed the surrounding soil to the pile body and left some surface curves and cracks. Some soil lumps were found on the external surface of both of the developed and ordinary steel pipe pile. Both of the steel pipe piles are stayed in a stable situation in terms of physical changes on the material. The added new parts (screws) also remained in a good condition. Only some soil lumps also found on each screw surface after extraction when the loading process was completed.

The applied method allowed clear differences in the observed results for both of the ordinary (Model I) and the modified (Model II) steel pipe piles. The direct relationship of the ordinary and the modified steel pipe piles was admitted. The maximum reduction percent was observed after a certain time and load application to be $36 \%$.

\subsection{Model I}

The recorded final settlement (Figs. 6, $7 \& 8$ ) magnitude for the ordinary pile was $10.3 \mathrm{~mm}$, which is about $36.3 \%$ more than Model II. The ordinary pile was loaded without any added parts. Therefore, the pile resisted loading normally depending on its material ability (steel). The pile surrounding surface was smooth, which may offered low fiction resistance with the contacting fine-grained soil. However, the end bearing was similar in both cases of models I and II.

The maximum settlement reading was observed $(10.4 \mathrm{~mm})$ at the end time of stress application stage of the ordinary pile when the maximum stress of 27.71 psi was achieved through both piles types (Figs. 6, 7\& 8).

\subsection{Model II}

The achieved reduction in the settlement can be from the added new parts (screws). The screws were inserted into the surrounding fine-grained soils and blocked strongly the movement after complete insertion. The addition of those screws 
physically increased the contact surface area between the pile circumferential area and the surrounding soil. Consequently, the addition of screws led to increase the surface friction interaction, and thus the pile capacity.

The recorded magnitude of the final settlement (Fig. 8) for the improved pile is $6.6 \mathrm{~mm}$, which is about $36 \%$ as an improvement percent for the pile capability. The added 12 screws (each three screws on the same vertical line, which resulted in four vertical lines) were worked well compare with the normal steel pipe pile.

Thus, the significant reduction of the improved steel pipe pile settlement (vertical linear movement) was associated with the addition of new parts (screws) (Figs. $6 \& 7$ ). Therefore, in the examined piles, the lower settlement $(6.6 \mathrm{~mm})$ was achieved throughout the modified pile. This can be explained by a positive role of the screws insertion to the surrounding soil sample, which was at the field density during sample preparation.

The expected increased pile capacity, proposed from skin friction as the end bearing capacity, is absolutely similar for both pile cases. As shown in Fig. 6, for the first three loadings, both of the two piles showed close behaviour and similar settlement readings achieved. Until the final loadings, approximately parallel behaviour was noticed. However, the normal pile showed higher settlement readings compare with the modified pile. The same described situation was achieved also in the time-settlement relationship showed in Fig. 7. Fig. 9 shows the settlement reduction (36 $\%$ ) obtained after the addition of new parts for the modified pile. After the third cumulative applied load, the settlement significantly reduced until the fourth loading. However, after that the settlement reduction got approximately constant magnitude.

Three main factors were selected to be analysed in order to discover their importance for the success of the proposed idea. These factors are settlement, time, and applied loads. Settlement has been decreased with the addition of the new parts (36\% reduction) (Figs. 6 up to Fig. 9). Time was an important factor to notice the role of the added parts. Figs. $6,7 \& 8$ show the decrease in the settlement magnitude with time. Within time progress, the proposed new parts will have a sufficient duration to be fixed properly in the surrounding soil. So, in a relaxed manner the added parts would play their role to insert larger surface area to contact the surrounding soil and to therefore increase the pile capability. Application of exactly the same loading process would help to discover the successfulness of the proposed idea (Fig. 2). From Figs. 6, $10 \& 11$, the stronger pile is the one with the added parts.

After the stress application of $8.8 \mathrm{kPa}$, the monitored pile settlement of model I was $1.23 \mathrm{~mm}$ and model II was $1.11 \mathrm{~mm}$ with a reduction percent of $10 \%$. After the stress application of 35 $\mathrm{kPa}$, the monitored pile settlement of model I was $4.75 \mathrm{~mm}$ and model II was $3.3 \mathrm{~mm}$ with a reduction percent of $31 \%$. After the stress application of $156 \mathrm{kPa}$, the monitored pile settlement of model I was $9.3 \mathrm{~mm}$ and for model II was $6.2 \mathrm{~mm}$ with a reduction percent of $33 \%$. After the stress application of $191 \mathrm{kPa}$, the monitored pile settlement of model I was $10.3 \mathrm{~mm}$ and model II was $6.6 \mathrm{~mm}$ with a reduction percent of $36 \%$.

The current experimental work does not include monitoring the behaviour of selected pile types in many cases of problematic soils. The method also does not allow direct observation of fully saturated soils or the piles response in a layered ground. Clearly, while the method is a more realistic representation of ordinary and modified steel pipe piles than solid ones, it does not directly simulate all the existing weak soil conditions likely to be encountered on site.

\subsection{Field application of the models}

In the field, practically, the steel pipe pile diameter is larger compare with the laboratory size. Therefore, more space existing to do the field work properly. Two scenarios may be possible to apply the model-II in the field. The first scenario is by addition of screws to the surrounding surface of the steel pipe pile. The screws would be rotating internally in order to be inserted in the surrounding soil until achieving the final length of the screw in order to be fixed inside the soil. The scenario may be applied in the layers of soft soils in the ground and in the cases of shallow length of piles (may be up to 10 meter). The second scenario is by increasing the hole location diameter for the pile in the field. The addition of the screws starts from the bottom side layer after layer. For each added layer of screws, the soil surrounding the pile surface should be added and compacted to the required density. The process continuous until achieving the top surface of the ground, which all of the added screws will be inserted in the surrounding soil. It should be noted that the current results are based on the laboratory work on small size physical model of the soil-pile 
system only. Therefore, more works would be needed to define the range for practical application/limitation of these scenarios in different soil systems and with high degree of confidence. The application of the proposed method of pipe pile in this study and considering the common screw piles and other pile types can be compared in the following points:

- The cost of this study method is quite less compare to the screw piles. In the proposed method no need for any hydraulic torque machine to install the piles. The selected pipe pile type and screws are cheaper. Less energy for installation also requires for the proposed method of this study.

- By considering above two piles installation scenarios for this study, various types of soils can be selected. The screw piles can be damaged in some cases of gravelly soils or rocks.

- The proposed method is considered for shallow soil depths, which can be used for many construction projects to resist tension/compression forces.

- The proposed method of this study is considering a pipe pile (may use diameter from 10 $\mathrm{cm}$ and more), requires horizontal screw installation, which provides more surface area in order to get more friction capacity.

\section{CONCLUSIONS}

Based on the laboratory work of two models I \& II, several conclusions can be observed:

1. Used screws as new parts worked perfectly to increase internally the steel pipe pile skin friction and to increase generally the steel pipe pile capacity.

2. Application of this new technique helped to reduce the total settlement of the pile by $36 \%$.

3. The recorded settlement was $1.23 \mathrm{~mm}$ and 1.11 $\mathrm{mm}$ for $8.8 \mathrm{kPa}$ applied stress for model I \& II respectively, which is $10 \%$ reduction. The recorded settlement was $4.8 \mathrm{~mm}$ and $3.3 \mathrm{~mm}$ for $35 \mathrm{kPa}$ applied stress for model I \& II respectively, which is $31 \%$ reduction. The recorded settlement was $9.3 \mathrm{~mm}$ and $6.2 \mathrm{~mm}$ for $156 \mathrm{kPa}$ applied stress for model I \& II respectively, which is $33 \%$ reduction. The recorded settlement was $10.3 \mathrm{~mm}$ and $6.6 \mathrm{~mm}$ for $191 \mathrm{kPa}$ applied stress for model I \& II respectively, which is $36 \%$ reduction.
4. The application of this modified version of pile is limited for fine-grained soils only, which showed improvement on their properties. Selection of sizes of the physical model of the soil and the pile depending on their successfulness to present an efficient research work.

5. The study procedures can be repeated easily and through a simple way the required data can be collected. The robust of the carried out experimental models can be duplicated for more future studies.

\section{Acknowledgments}

The author is grateful to geotechnical engineering laboratory staff who support through using the lab facilities, and to the Civil Engineering Department of University of Sulaimani, Kurdistan Region of Iraq.

\section{References}

- Adsero, M. E. (2008). Effect of jet grouting on the lateral resistance of soil surrounding driven-pile foundations. MSc Thesis, Brigham Young University.

- Ackley, R. E., \& Sanders, R. L. (1979). Load Tests on Piles Driven into Cretaceous Sand. In Symposium on Deep Foundations: . ASCE.

- Al-Waily, M., J., M., Al-Ta'ai, A., A., S., \& AlJanabi, S., M., H. (2013). A Comparative Study between Piled-Raft and Two Soil Improvement Techniques. Eng. \& Tech. Journal, 31 Part A (20), pp. 409-421.

- Al-Waily, M., J., M., Al-Dabbas, M., S., F., \& Jasim, M., H. (2014). Experimental Study of the Behavior of Circular Footing on Cohesive Soil Stabilized with Gravel. URL:https://www.researchgate.net/publication/3 15780373_Experimental_Study_of_the_Behavi or_of_Circular_Footing_on_Cohesive_Soil_Sta bilized_with_Gravel.

- Axtell, P. J., Owen, J. W., \& Vollink, S. D. (2004). Increase in pile capacity with time in Missouri River alluvium. Proceedings: Fifth International Conference on Case Histories in Geotechnical Engineering, New York, NY, April 13-17.

- BS 1377-4 (1990). Methods of test for soils for civil engineering purposes. Compaction-related tests. British Standards.

- Clayton D. J. (2005). Basic Helical Screw Pile Design. Earth Contact Products, LLC.

- Costa, Y. D., Cintra, J. C., \& Zornberg, J. G. (2003). Influence of matric suction on the results of plate load tests performed on a lateritic soil 
deposit. Geotechnical Testing Journal, ASTM International 26 (2).

- Dasenbrock, D. D. (2007). Time Dependent Behavior and Capacity Assessment of Open-Ended Pipe Piles. 55th Annual Geotechnical Engineering Conference.

- Dash, S. K., Sireesh, S., \& Sitharam, T. G. (2003). Model studies on circular footing supported on geocell reinforced sand underlain by soft clay. Geotextiles and Geomembranes, 21 (4), pp. 197-219.

- Douthitt, B., Houston, W., Houston, S., \& Walsh, K. (1998). Effect of wetting on pile friction. In Proceedings of 2nd International Conference on UNSAT, pp. 219-224.

- El Sawwaf, M., \& Nazir, A. (2011). Behavior of eccentrically loaded small-scale ring footings resting on reinforced layered soil. Journal of Geotechnical and Geoenvironmental Engineering, 138 (3), pp. 376-384.

- Fattah, M., Y., Shlash, K., T., \& Al-Waily, M., J. (2013). Experimental evaluation of stress concentration ratio of model stone columns strengthened by additives. International Journal of Physical Modelling in Geotechnics, 13 (3), pp. 79-98.

- Fattah, Mohammad Y., Mohammad M. Al-Ani, and Mahmoud TA Al-Lamy (2014). Studying collapse potential of gypseous soil treated by grouting. Soils and Foundations, 54 (3), pp. 396-404.

- Fattah, M., Y., \& Al-Waily, M., J., M. (2015). Bearing capacity of Foundations Resting on a Trench of Local Reclaimed Asphalt Pavement Material. Global Journal of Engineering Science and Research Management, 2 (12), pp. 90-105.

- FinnRA (2000). Steel Pipe Piles. In Finnish National Road Administration, Bridge Engineering, FIN0521 Helsinki, Finland.

- Georgiadis, K., Potts, D. M., \& Zdravkovic, L. (2003). The influence of partial soil saturation on pile behaviour. Géotechnique, 53 (1), pp. 1125.

- Ghazavi, M., \& Ahmadi, H. A. (2008). Timedependent bearing capacity increase of uniformly driven tapered piles-field load test. Sixth International Conference on Case Histories in Geotechnical Engineering, Arlington, VA, August 11-16.

- Gueguin, M., Hassen, G., \& Buhan, P. (2015). Ultimate bearing capacity of a foundation reinforced by columns or cross trenches under inclined loads: a homogenization approach. International Journal for Numerical and Analytical Methods in Geomechanics, 39 (3), pp. 277-294.

- Herbst, M. A. (2008). Impact of mass mixing on the lateral resistance of driven-pile foundations. M.Sc. Thesis, Brigham Young University.

- Kessler, K. A. (1979, October). Case History: Pile Foundation in Flood Plain Soils. In Symposium on Deep Foundations, ASCE, pp. 215-234.

- Lemme, N. A. (2010). Effectiveness of Compacted Fill and Rammed Aggregate Piers for Increasing Lateral Resistance of Pile Foundations. M.Sc. Thesis, Brigham Young University.

- Mohammed, A. S., \& Vipulanandan C. (2014). Compressive and tensile behavior of polymer treated sulfate contaminated CL soil. Geotechnical and Geological Engineering, 32 (1), pp. 71-83.

- Olson, R.E. (2003). Axial Load Capacity of Individual Driven Piles. 51 ${ }^{\text {st }}$ Annual Geotechnical Engineering Conference.

- Ornek, M., Demir, A., Laman, M., \& Yildiz, A. (2012). Numerical Analysis of Circular Footings on Natural Clay Stabilized With A Granular Fill. ACTA GEOTECHNICA SLOVENICA, 1, pp. 6175.

- Practice Note 28 (2015). Screw Piles: Guidelines for Design, Construction and Installation. Version 1.

- Seo, H., Prezzi, M., \& Salgado, R. (2008). Settlement analysis of axially loaded piles. Sixth International Conference on Case Histories in Geotechnical Engineering, Arlington, VA, August 11-16.

- Tappenden K. M. (2007). Predicting the Axial Capacity of Screw Piles Installed in Western Canadian Soils. M.Sc. Thesis, Department of Civil and Environmental Engineering, University of Alberta, Canada.

- Tomlinson, M., \& Woodward, J. (2014). Pile design and construction practice. Sixth Edition, CRC Press, Taylor \& Francis Group.

- Unnikrishnan, N., Rajan, S., \& Johnson, A. S. (2011). Bearing capacity of strip footings on encapsulated granular Trenches. Proceedings of Indian Geotechnical Conference, Kochi, December 15-17, Paper ID-141.

- Vanapalli, S. K., \& Taylan, Z. N. (2011). Estimation of the shaft capacity of model piles in a compacted fine-grained unsaturated soil. In 14th Pan-Am Conf. on Soil Mechanics and Geotechnical Engineering \& 64th Canadian Geotechnical Conf., Toronto, Canada.

- Yttrup P. J. \& Abramsson G. (2003). Ultimate Strength of Steel Screw Piles in Sand. Australian Geomechanics, 38 (1), pp. 17-27. 
Table (1):Physical properties of the study soil.

\begin{tabular}{|c|c|c|}
\hline Properties & Values & ASTM \\
\hline Natural moisture content, $\omega(\%)$ & 16 & D $2216-10$ \\
\hline Field density, $\rho_{\mathrm{f}}\left(\mathrm{gm} / \mathrm{cm}^{3}\right)$ & 1.91 & D 2937-10 \\
\hline Dry density, $\rho_{d}\left(\mathrm{gm} / \mathrm{cm}^{3}\right)$ & 1.64 & \\
\hline Initial void ratio & 0.56 & Craig (2004) \\
\hline Porosity (\%) & 0.36 & \\
\hline Liquid Limit (\%) & 57 & D $4318-10$ \\
\hline Plastic Limit (\%) & 28 & \\
\hline Plasticity Index & 29 & \\
\hline Liner shrinkage Limit (\%) & 14.3 & C $356-10$ \\
\hline Coefficient of Compressibility $\left(\mathrm{C}_{c}\right)$ & 0.18 & D 2435- 11 \\
\hline Coefficient of Swelling $\left(\mathrm{C}_{\mathrm{r}}\right)$ & 0.021 & \\
\hline Swelling Pressure $\left(\mathrm{kN} / \mathrm{m}^{2}\right)$ & 25 & D 4546-14, method A \\
\hline Cohesion $\left(\mathrm{kN} / \mathrm{m}^{2}\right)$ & 15 & D $3080-11$ \\
\hline Angle of Internal Friction (Degree) & 27.5 & \\
\hline Unconfined Compressive Strength $\left(\mathrm{kN} / \mathrm{m}^{2}\right)$ & 302.6 & D 2166-16 \\
\hline $\begin{array}{l}\text { Soil type } \\
\end{array}$ & $\mathrm{CH}$ & D 2487-00 \\
\hline
\end{tabular}

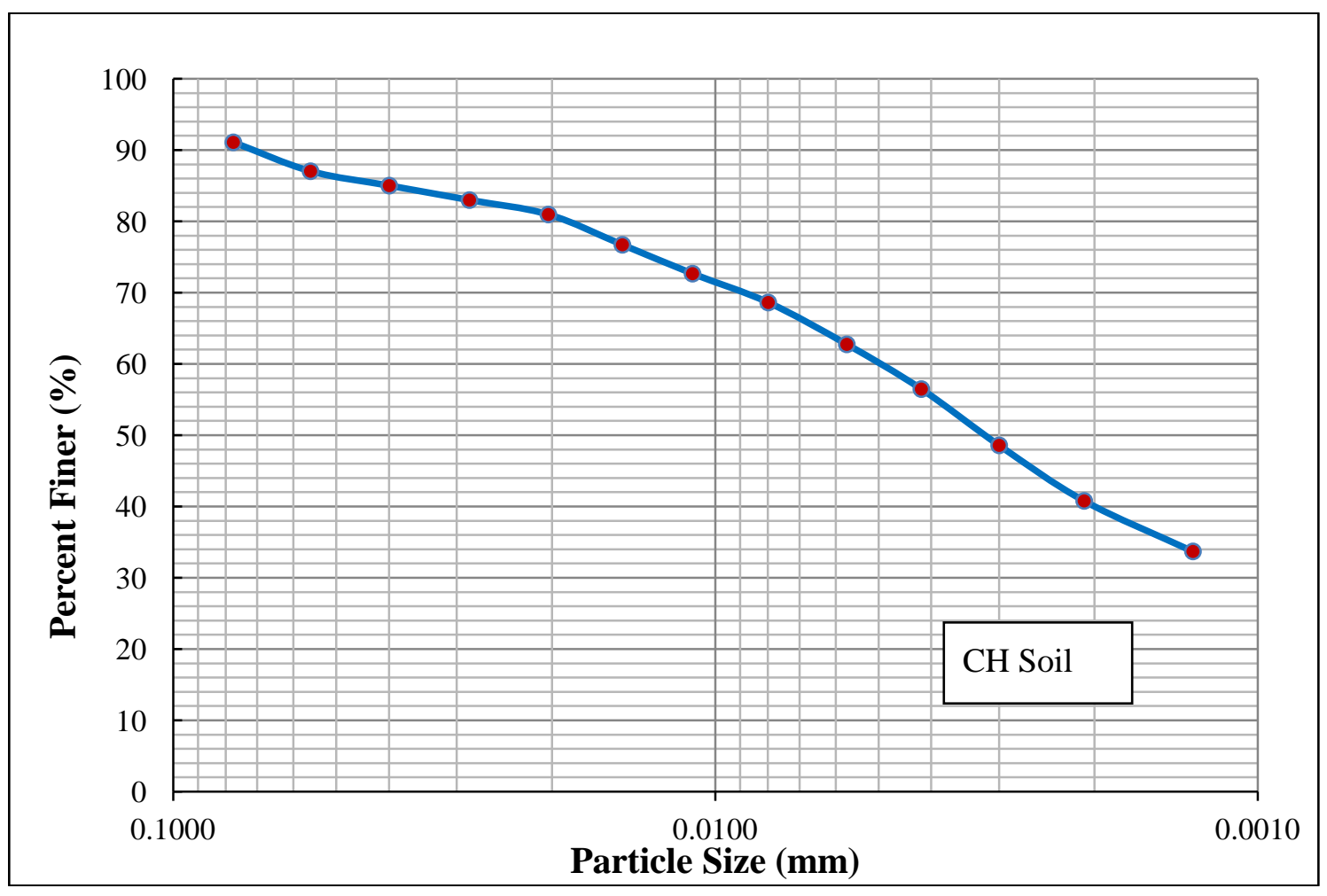

Fig. (1): Particle size distribution for the soil used. 


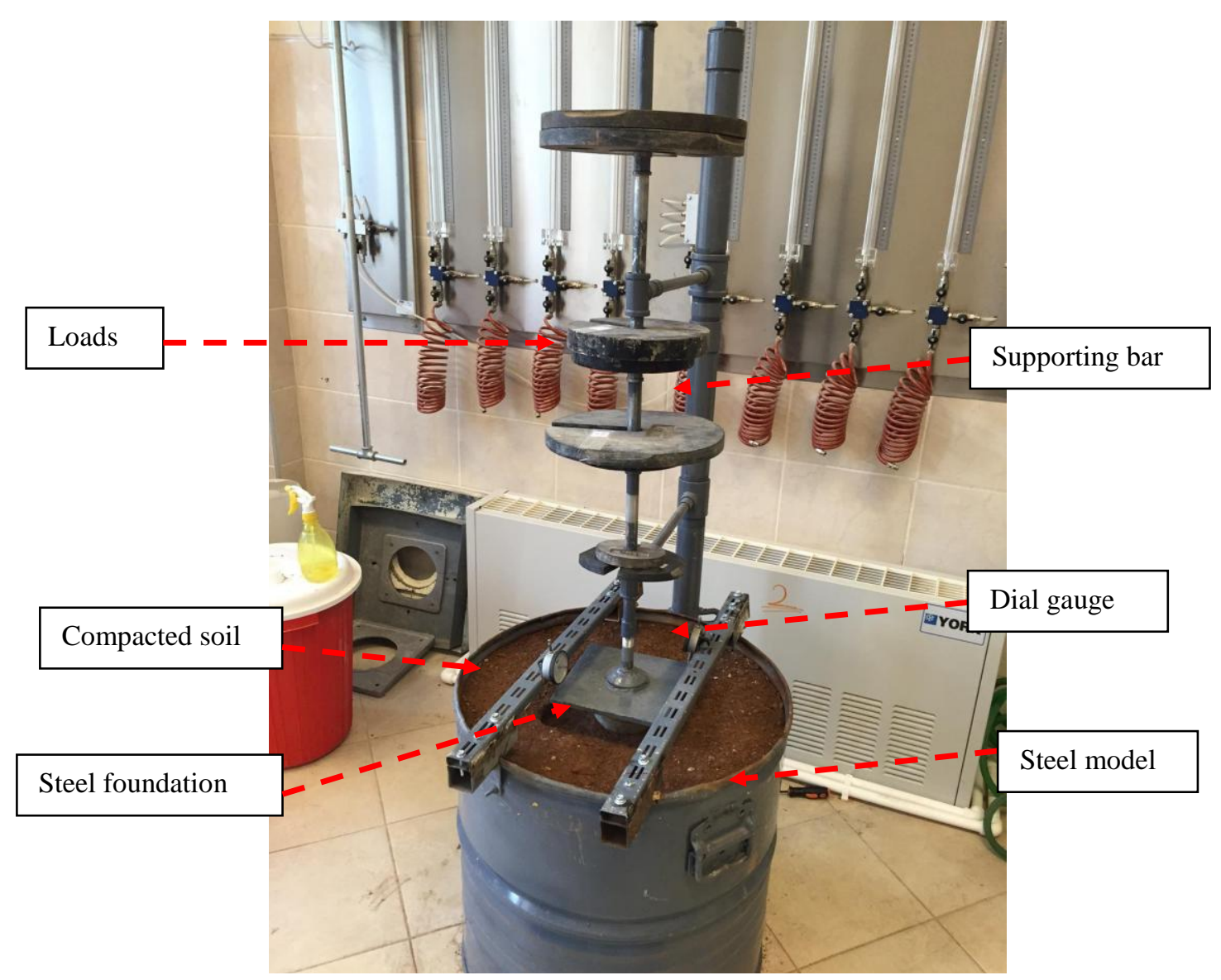

Fig. (2): Physical model with accessories.

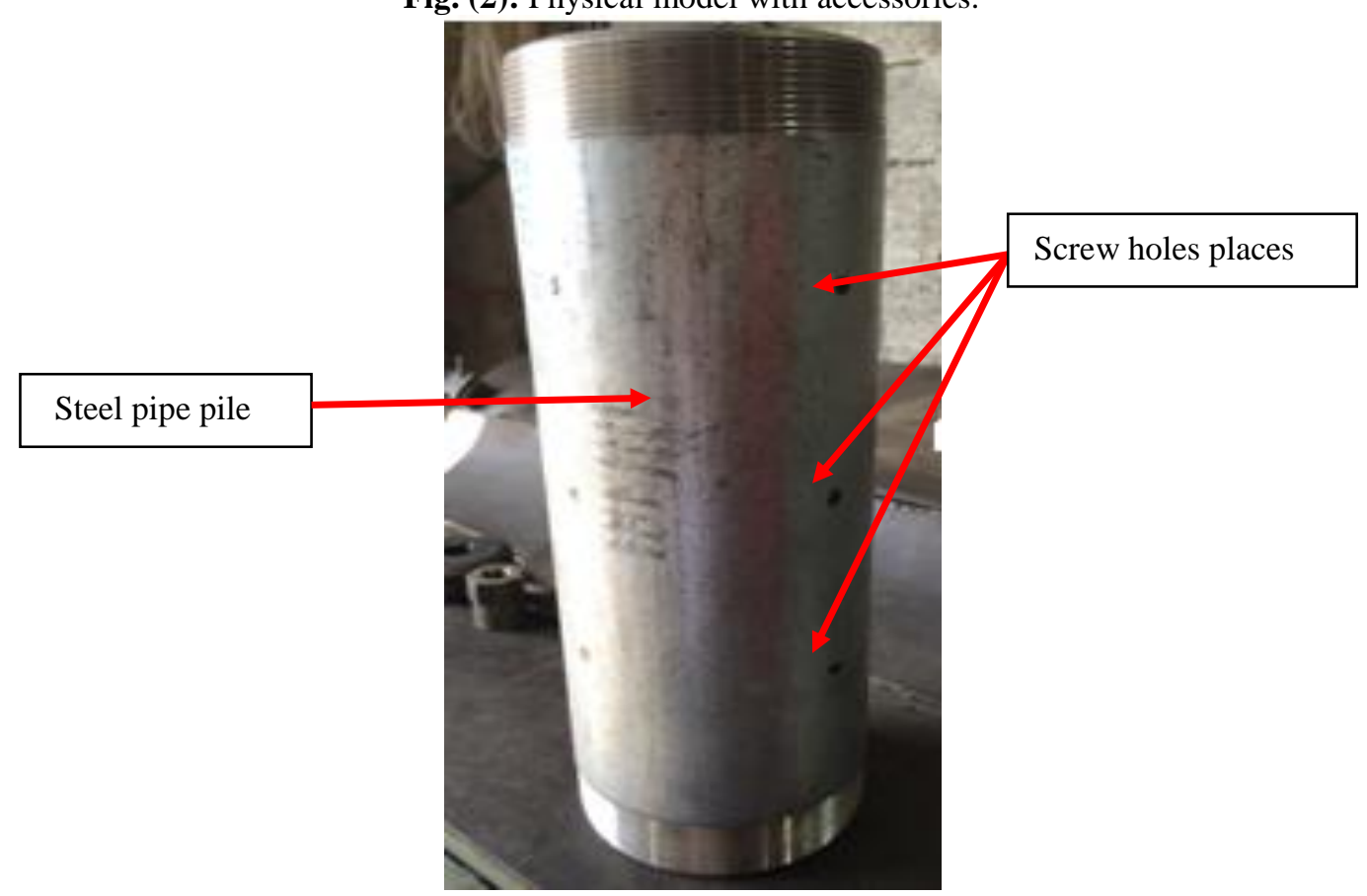

Fig. (3): Steel pipe piles without addition of screws. 


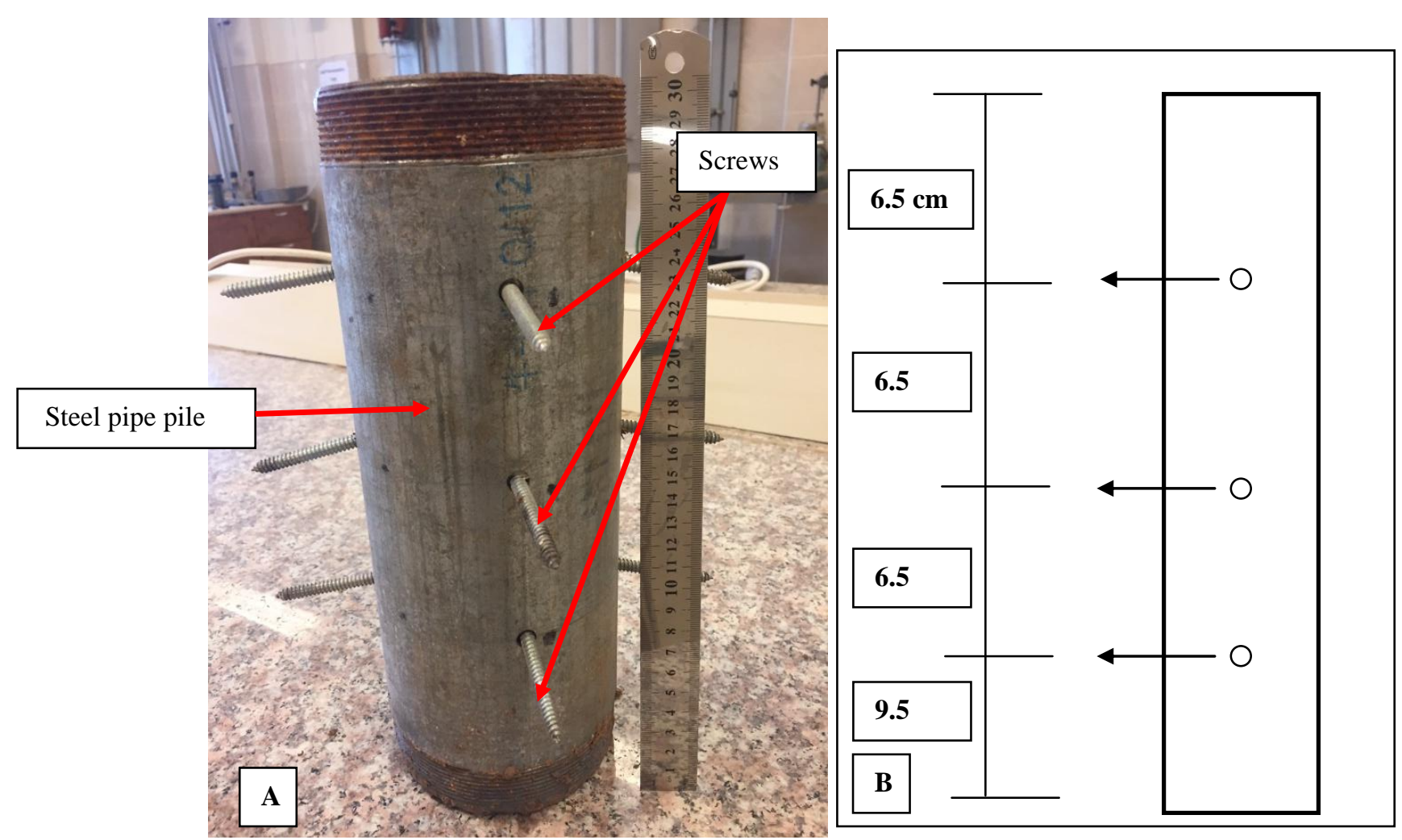

Fig. (4): Steel pipe pile modified by the addition of screws.

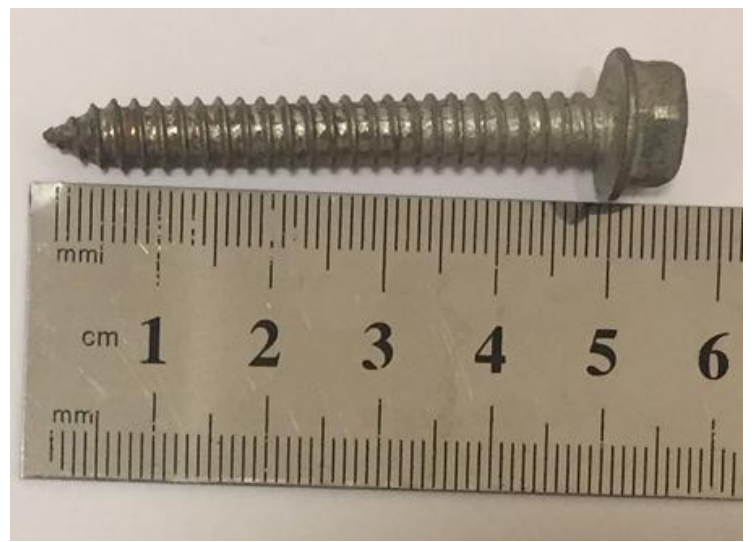

Fig. (5): Steel screw used as the new parts added to the ordinary steel pipe pile at certain distances on the circumferential pile surface. 


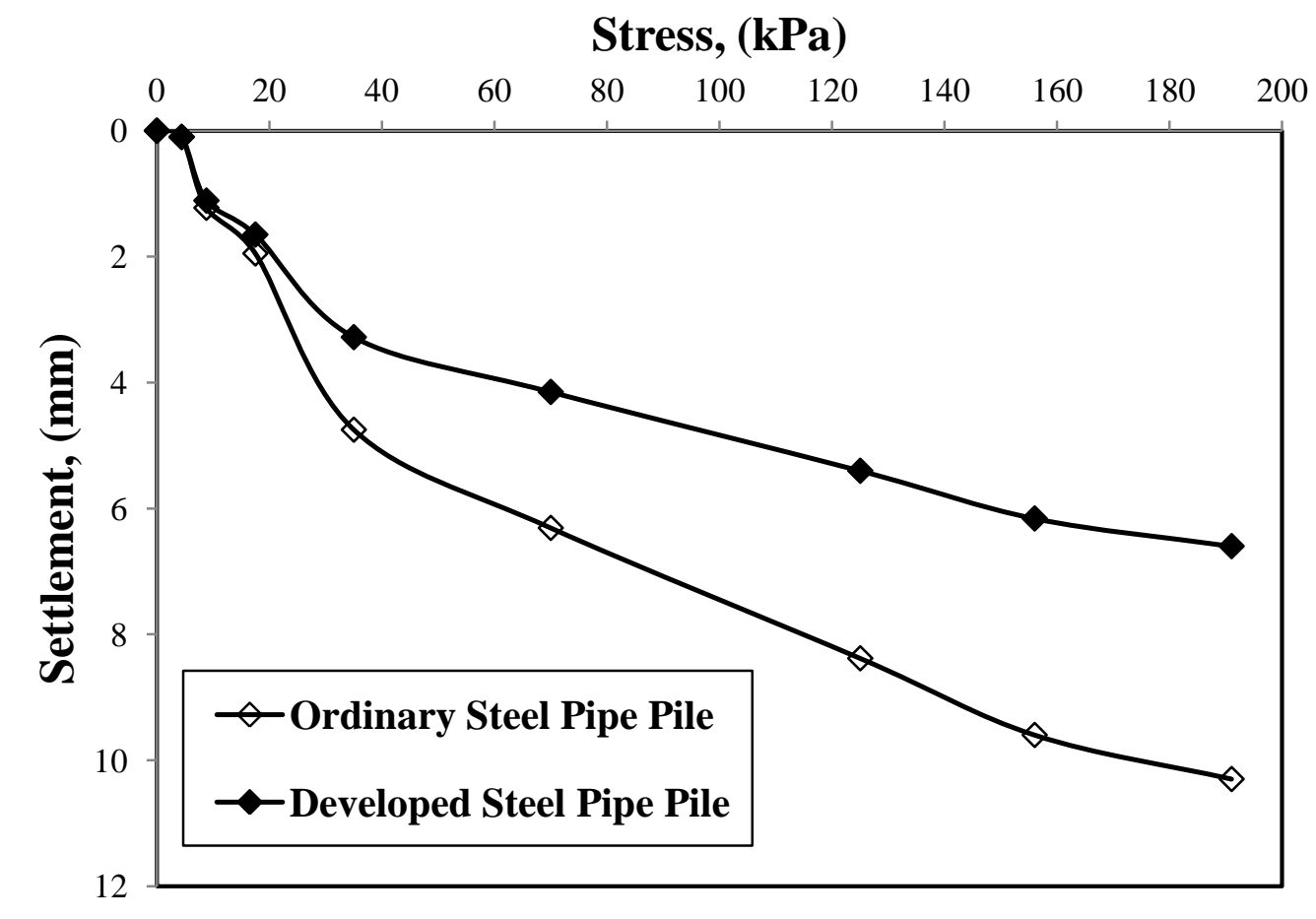

Fig. (6): Load-settlement relationship for the ordinary and modified steel pipe piles.

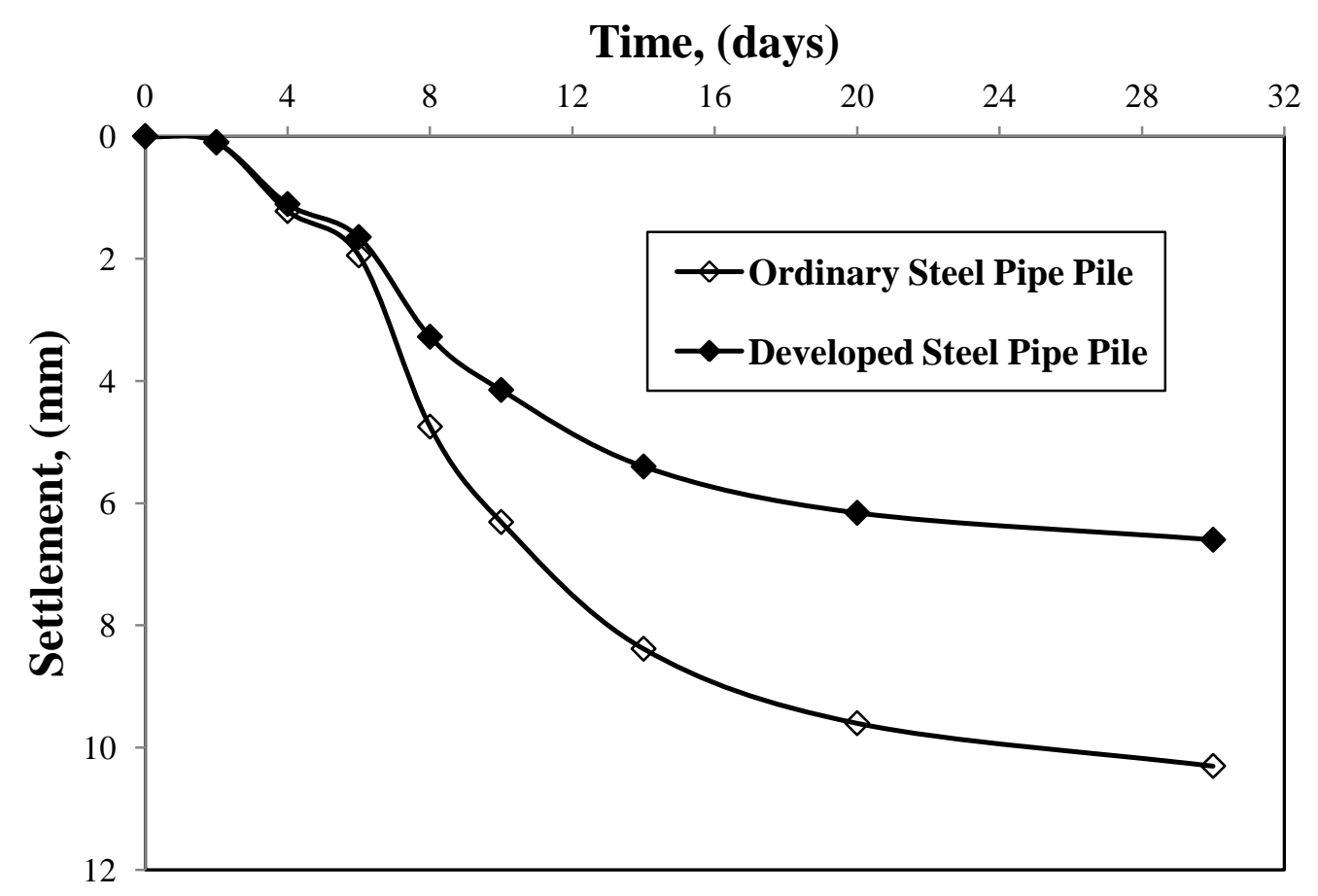

Fig. (7): Time-settlement relationship for the ordinary and the modified steel pipe piles. 


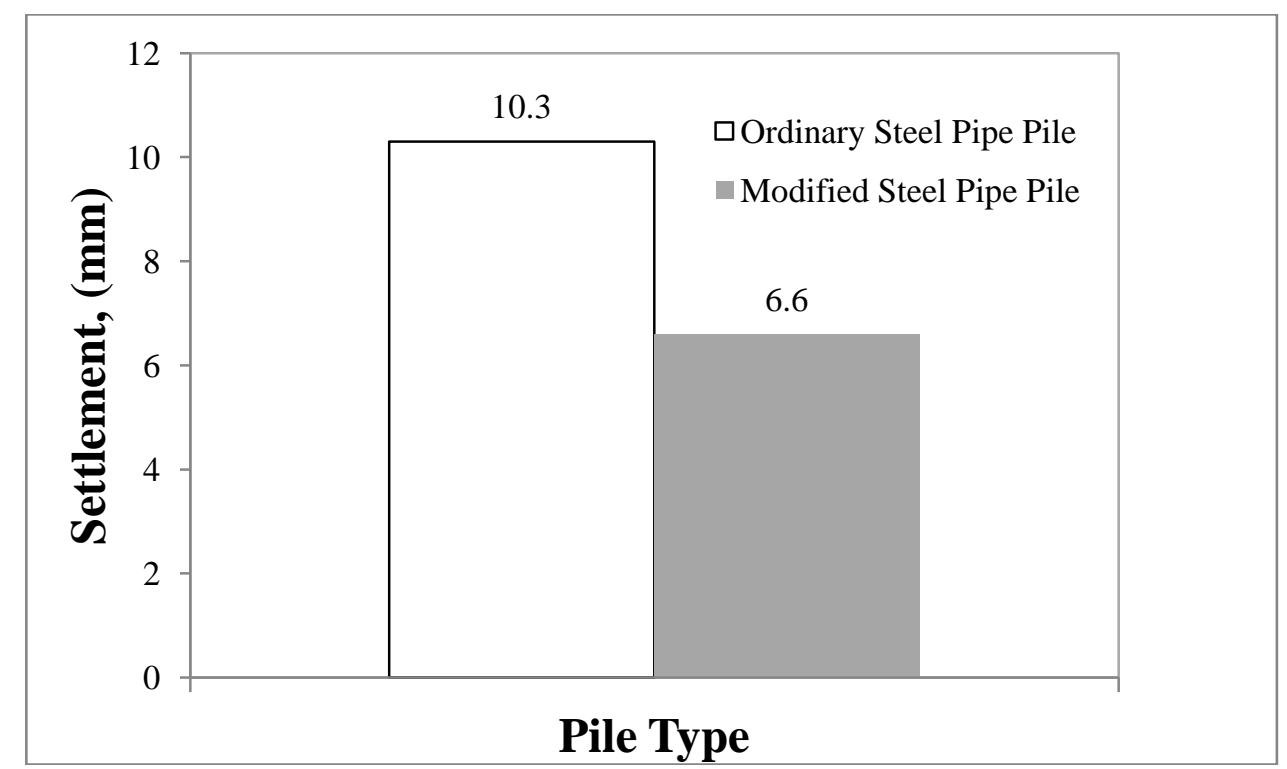

Fig. (8): Maximum recorded settlement for the ordinary and the modified steel pipe piles.

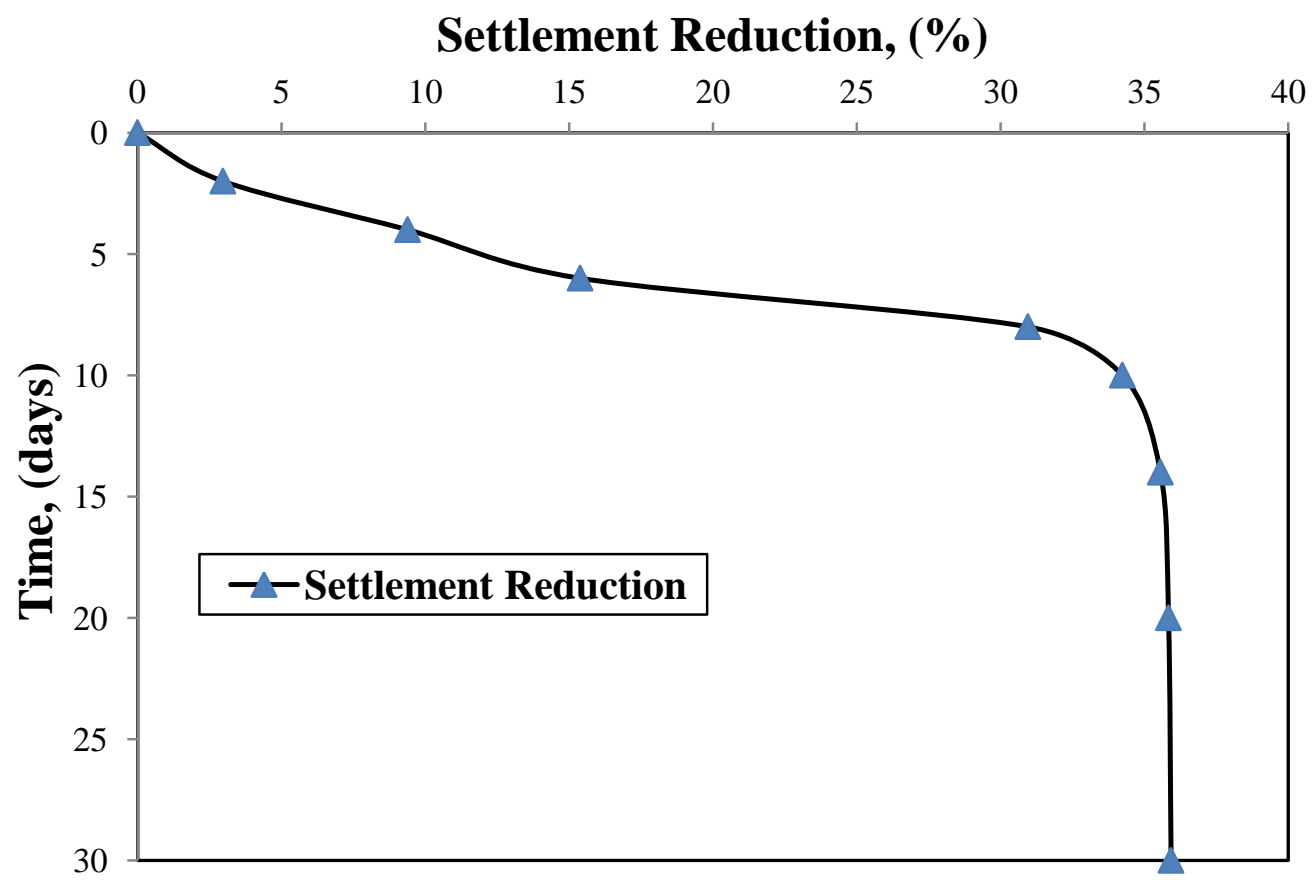

Fig. (9): Relationship between time and settlement reduction due to the improvement of the steel pipe piles by the addition of new parts (screws). 


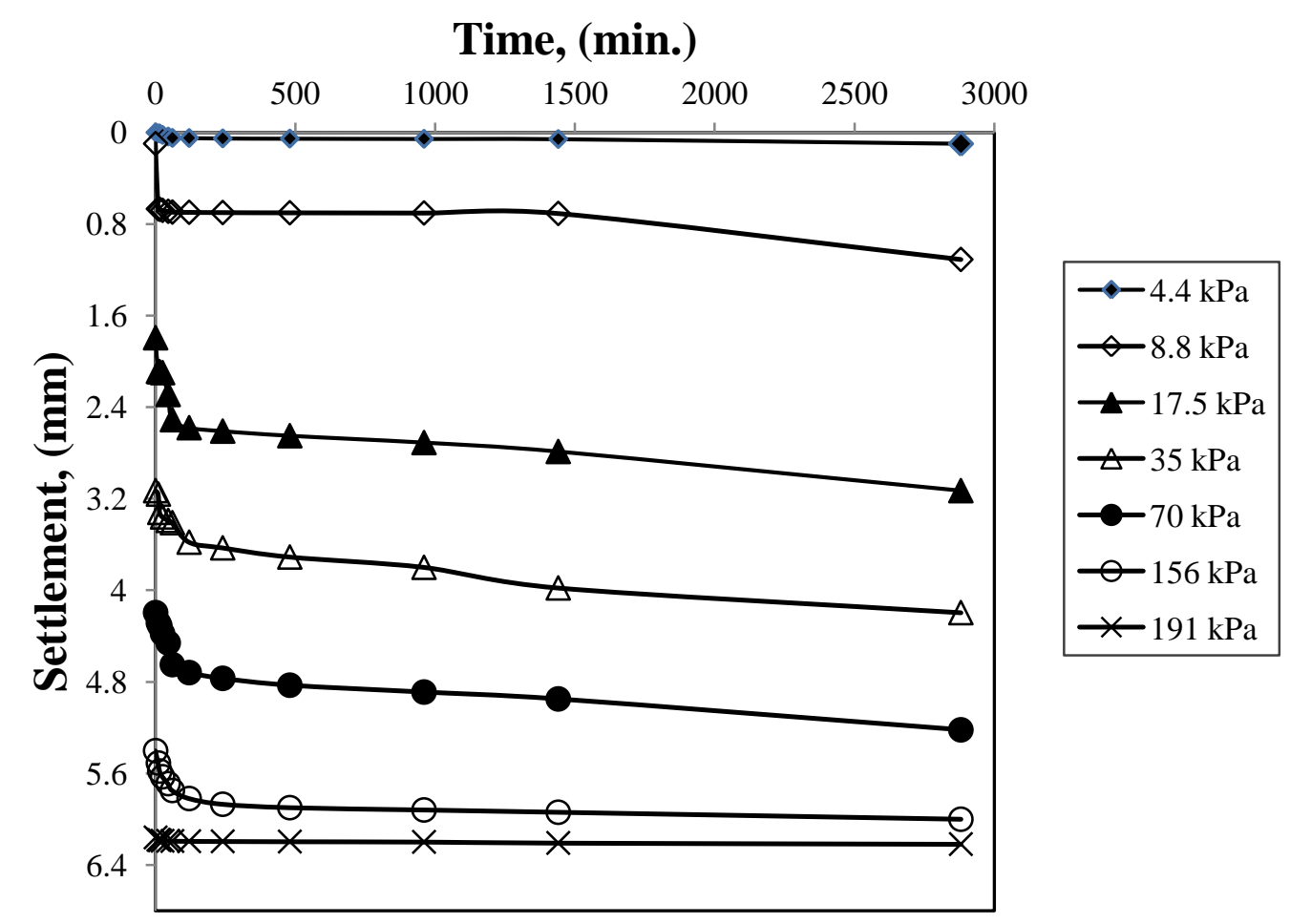

Fig. (10): Time-settlement relationship for the modified steel pipe pile for each loading stage.

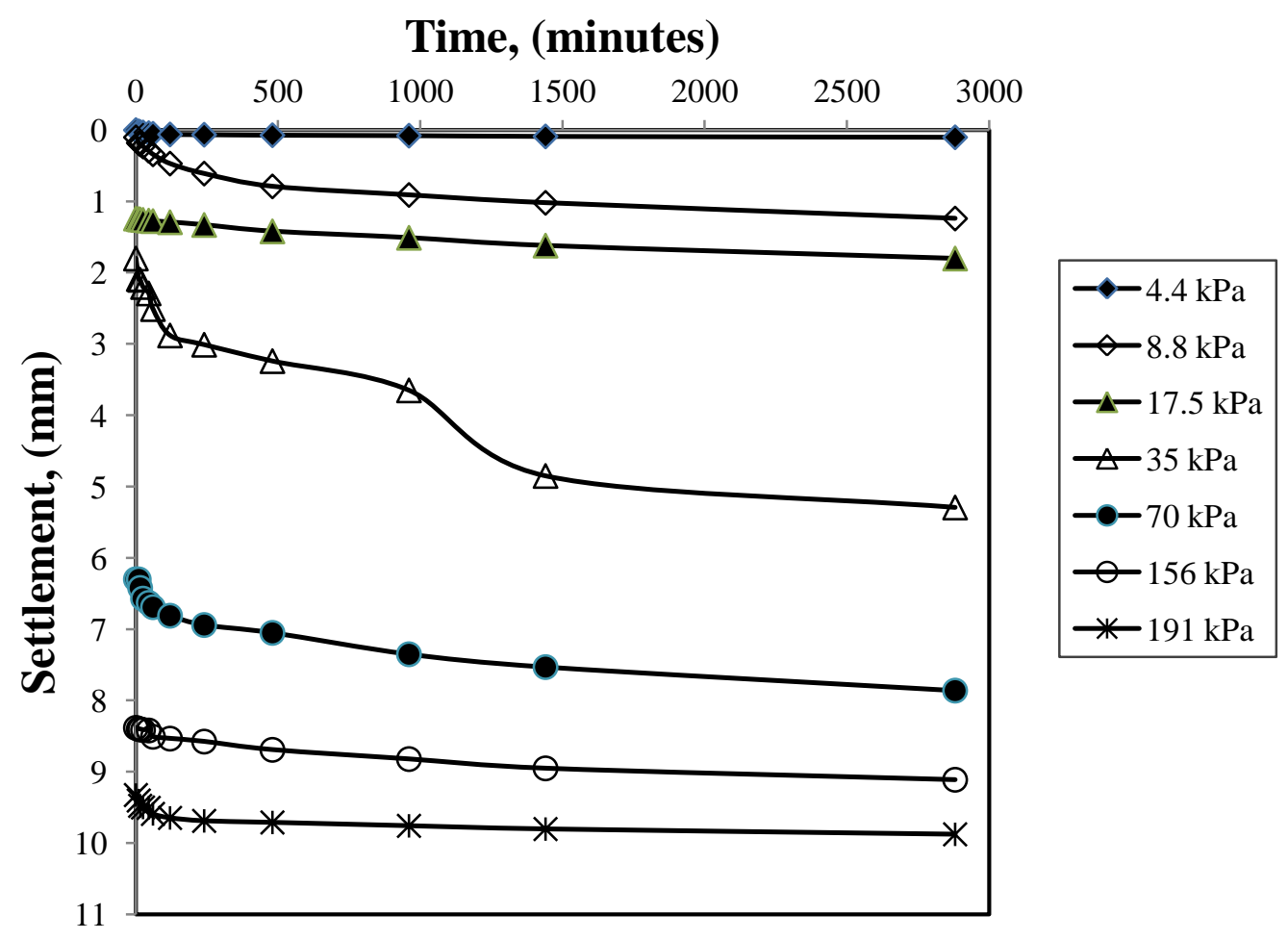

Fig. (11): Time-settlement relationship for the ordinary steel pipe pile for each loading stage. 